\title{
Estimation of soil loss by the USLE model in a mountain basin in the south of Santa Catarina state, Brazil
}

\author{
Estimativa de perdas de solos pelo modelo USLE em bacia hidrográfica de \\ região montanhosa no sul de Santa Catarina, Brasil
}

\author{
Lucas Kister Amaral' \\ Sabrina Baesso Cadorin" \\ Álvaro José Back"I \\ Fernanda Dagostin Szymanski ${ }^{i v}$ \\ Claudia Weber Corseuilv
}

\begin{abstract}
Water erosion is a factor of soil degradation that is triggered by the impact of raindrops originated by intense rainfall disaggregating the soil, followed by the carrying of particles by surface runoff. In the erosion process, in addition to soil loss, nutrients, fertilizers, and pesticides are carried resulting in water courses and water pollution. Erosion can have a major impact on agricultural production, when land use and management techniques are not used. Therefore, this study aimed to evaluate the soil loss in the Malacara river basin, which is a sub-basin of the Mampituba river basin characterized by a contrasting relief, with high altitudes in the escarps of Serra Geral and floodplain. The method used for the development of this research was the application of the Universal Soil Loss Equation (USLE). USLE soil loss estimation requires the following factors: rainfall erosivity $(R)$, soil erodibility $(K)$, slope length $(L)$, slope steepness $(S)$, land use and management $(C)$, and erosion control practice factor $(P)$. The estimated rainfall erosivity was $5,754.2 \mathrm{MJ} \mathrm{mm} \mathrm{ha-1} \mathrm{h}^{-1}$ year ${ }^{-1}$. Erodibility was determined for the soils present in the basin, highlighting a high value for gleysoil. The topographic factor $(L S)$ showed values from 0 to greater than 20, which corresponds to the low to very high runoff potential. The floodplain showed lower runoff rates, while for the locations close to the enclosed valleys in the Malacara canyon, the runoff potential varied from high to very high. The land use and management factors and conservation practices $(C P)$ obtained a maximum value of 0.404 , corresponding to the exposed soil; the second most representative class was agricultural areas, with a value of 0.145 . The soil loss in the Malacara river basin varied from 0 to more than $200 \mathrm{t} \mathrm{ha}^{-1}$ year-1. In fact, $87.38 \%$ of the area presents a degree of sheet erosion normal to slight and, only $2.94 \%$ of the area has a high or very high degree of erosion. Moreover, due to the relief characteristics with shallow soils and intense rainfall in mountainous basins, knowing and understanding soil losses due to erosion is crucial for the adequate management of water resources in river basins.
\end{abstract}

Keywords: Water erosion; GIS; Mountain river basin.

'Universidade do Extremo Sul Catarinense, Criciúma, SC, Brasil - lucas.sustentavel@gmail.com.

"Universidade do Extremo Sul Catarinense, Criciúma, SC, Brasil - bcadorin.sabrina@gmail.com.

I"Empresa de Pesquisa Agropecuária e Extensão Rural de Santa Catarina, Estação Experimental de Urussanga, Urussanga,

SC, Brasil - ajb@epagri.sc.gov.br.

IVUniversidade Federal de Santa Catarina, Florianópolis, SC, Brasil - f.dagostin@posgrad.ufsc.br.

VUniversidade Federal de Santa Catarina, Florianópolis, SC, BRasil - claudia.weber@ufsc.br. 


\section{Resumo}

A erosão hídrica é um fator de degradação do solo que é desencadeado pelo impacto das gotas de chuvas originadas por precipitações intensas, desagregando o solo, seguido pelo carreamento das partículas pelo escoamento superficial. No processo de erosão, além de perdas de solos, ocorre carreamento de nutrientes, fertilizantes, defensivos agrícolas e, dessa forma, ocorrem os processos de assoreamento dos cursos d'água e poluição dos recursos hídricos. A erosão pode gerar grande impacto na produção agrícola, quando não são realizadas técnicas de uso e manejo do solo. Nesses aspectos, o presente trabalho teve como objetivo avaliar a perda de solos na bacia hidrográfica do rio Malacara, que é uma sub-bacia da bacia do rio Mampituba, caracterizada por um relevo contrastante, com grandes altitudes nas escarpas da Serra Geral e a planície de inundação. O método utilizado para o desenvolvimento da pesquisa foi aplicação da Equação Universal de Perda de Solo (USLE). A estimativa da perda de solo pela USLE requer os fatores: erosividade da chuva (R), erodibilidade do solo $(K)$, comprimento da vertente $(L)$, declividade da vertente $(S)$, uso e manejo do solo (C) e práticas conservacionistas $(P)$. A erosividade da chuva estimada foi de $5.754,2 \mathrm{MJ} \mathrm{mm} \mathrm{ha-1} \mathrm{h}^{-1}$ ano-1. A erodibilidade foi determinada para os solos presentes na bacia, destacando um elevado valor para o Gleissolos. O fator topográfico (LS) apresentou valores de 0 a maiores que 20, que corresponde ao potencial de escoamento superficial baixo a muito alto. A planície de inundação apresentou taxas de escoamento superficial menores, enquanto os locais próximos aos vales encaixados, no cânion Malacara, o potencial de escoamento superficial variou de alto a muito alto. Os fatores de uso e manejo do solo e de práticas conservacionistas (CP) obtiveram valor máximo de 0,404 , correspondente ao solo exposto, a segunda classe mais representativa foi áreas agrícolas, com valor 0,145. A perda de solo na bacia hidrográfica do rio Malacara, variou de 0 a mais de $200 \mathrm{t} \mathrm{ha}^{-1} \mathrm{ano}^{-1}$, onde $87,38 \%$ da área apresenta um grau de erosão laminar normal a ligeiro e, apenas 2,94\% da área possui um alto ou muito alto grau de erosão. Adicionalmente, devido às características de relevo, solos pouco profundos, precipitações intensas nas bacias montanhosas, conhecer e compreender as perdas de solo por erosão é de extrema relevância para o adequado gerenciamento de recursos hídricos de bacias hidrográficas.

Palavras-chaves: Erosão hídrica; SIG; Bacia montanhosa. 


\section{Introduction}

Soil losses from water erosion have been considered worldwide as one of the most important environmental problems, especially in tropical and subtropical climates (MELLO et al. 2013). Erosion is a process in which soil particles are released from the cohesive matrix of the soil and then carried in the downstream direction by one of the transport agents (MINELLA et al., 2007).

The process of water erosion is triggered by the impact of raindrops on the soil and runoff (KINNELL, 2010), with land use being one of the key factors that influence susceptibility to soil erosion (MINELLA et al., 2007). Panachuki et al. (2006) point out that the impacts caused by anthropic interference, such as the removal of forests, expose the soil to natural actions in places of great rainfall affecting the productive capacity of the soils. Barbosa et al. (2015) mention that the main effects of water erosion are: the reduction of the productive potential of crops, pollution of water resources, and silting due to the transport of soil and sediment particles to water courses.

The main factors that influence erosion processes are rain, the topography of the land, the vegetation cover, and the nature of the soil (BERTONI; LOMBARDI NETO, 2012). In Brazil, the eastern portion, which extends from north to south, is predominantly characterized by mountainous river basins. These basins have great height variations between the top of the hills and the plain, as well as a steep slope with the predominance of orographic rains (KOBIYAMA et al., 2018). Orographic rainfall is a frequent phenomenon characterized by having variable intensity, long duration, and covering relatively small areas (BACK, 2013).

Furthermore, mountainous regions, as highlighted by Kuksina et al. (2017), intensify the rain convection process, enhancing the ability to generate runoff. In these regions, the hydrological response is triggered by factors such as temperature, precipitation, soil, lithology, vegetation, and slope (IVES; MESSERLI, 1989; STOFFEL et al., 2016). In addition to these factors, land use and occupation in these regions, according to Kobiyama et al. (2018), has intensified and this usually happens without planning, compromising conservation and environmental preservation. Based on these aspects, it can be said that these factors favor the occurrence of water erosion in mountain river basins. 
According to Minella et al. (2007), water erosion is the main consequence of intensified land use and occupation, causing a reduction in the productive capacity of soils and an increase in the transfer of sediments and pollutants to water bodies. Thus, for environmental planning and adoption of practices that enable soil and water conservation, information on soil loss is crucial (BACK; POLETO, 2018).

Soil losses can be estimated by empirical equations developed to predict soil loss, based on factors related to climate, soil, topography, vegetation, and soil management. Currently, there are a variety of empirical models to estimate water erosion such as: the Universal Soil Loss Equation-USLE proposed by Wischmeier and Smith (1978); the Universal Modified Soil Loss Equation-MUSLE Equation developed by Williams and Berndt (1977); the Universal Soil Loss Equation Revised (RUSLE 1) by Renard et al. (1997) and USLE-M (KINNELL; RISSE, 1998). These models are modified versions of the USLE, and were proposed with the aim of adding or replacing parameters to improve the soil losses estimation due to water erosion. Kinnell (2010) presents a detailed review of the parameters and the family of soil loss equations derived from USLE.

The USLE model, the focus of this study, integrates all the universally known factors that affect soil water erosion, that is, runoff, soil, slope length, degree of slope, cover, and land use and management practices for erosion control (WISCHMEIER; SMITH, 1978). The soil loss estimated by the USLE is the result of a multiplication of six factors, which are: soil erodibility $(K)$, soil cover and management $(C)$, conservation practices $(P)$, rain erosion $(R)$, length $(L)$, and slope $(S)$ of the area (BACK; POLETO, 2018).

These factors can be obtained from secondary data (soil maps, rainfall, land use and cover, etc.), of remote sensing images or aerial photographs (drones or aircraft). In addition, these data can be modeled and integrated in a computational environment using Geographic Information Systems (GIS) which enables to estimate soil losses in a distributed way in the river basin.

For this reason, studies in various parts of the world have used these technologies to estimate soil losses due to water erosion, as well as their individualized factors as shown by different studies (PANAGOS, 2015; BACK; POLETO, 2018; POLETO, 2018; KINNELL, 2010; 
BARBOSA et al., 2015). The use of GIS software for the application of USLE has shown great potential to assist in environmental planning, especially due to the ease of visualization, data integration, and speed of execution of results (PINTO; GARCIA, 2011).

In the south of Brazil, in the eastern part of Santa Catarina State, the relief is characterized by steep and rugged forms, with rivers that flow in strongly enclosed valleys, which open on the plain forming deposits of alluvial fans. The steeps are modeled on rocks of the Serra Geral formation, especially basaltic spills, where the Atlantic Forest vegetation (Dense Ombrophylous Forest) predominates.

The flatter part of this region is formed by coarse basaltic (gravels, pebbles, and rocks), sandy, and clayey sediments (SCHEIBE et al., 2010). Currently, the Atlantic Forest is quite altered, mainly in the flat areas and smooth slopes, where it has been replaced by agricultural crops (rice, bananas, corn, beans, etc.). On the steep slopes, the vegetation is more preserved, but it consists of secondary Atlantic forest and small fragments of reforestation of pine and eucalyptus. In this region, studies related to soil losses due to water erosion are still rare; therefore, it is important to understand the effects of climate and relief on soil erosion.

Thus, the goal of this study was to evaluate the soil loss in the Malacara river basin located in the mountainous region of southern Santa Catarina State, using the USLE model with GIS assistance.

\section{Material and Methods}

\subsection{Study area}

The Malacara river basin is a sub-basin of the Mampituba river basin area $\left(1,940 \mathrm{~km}^{2}\right)$ which covers two states in southern Brazil, Santa Catarina State and Rio Grande do Sul State (Figure 1). The Malacara river basin has a total area of $40.48 \mathrm{~km}^{2}$ with a perimeter corresponding to $38.10 \mathrm{~km}$. 
Figure 1 - Malacara River basin location

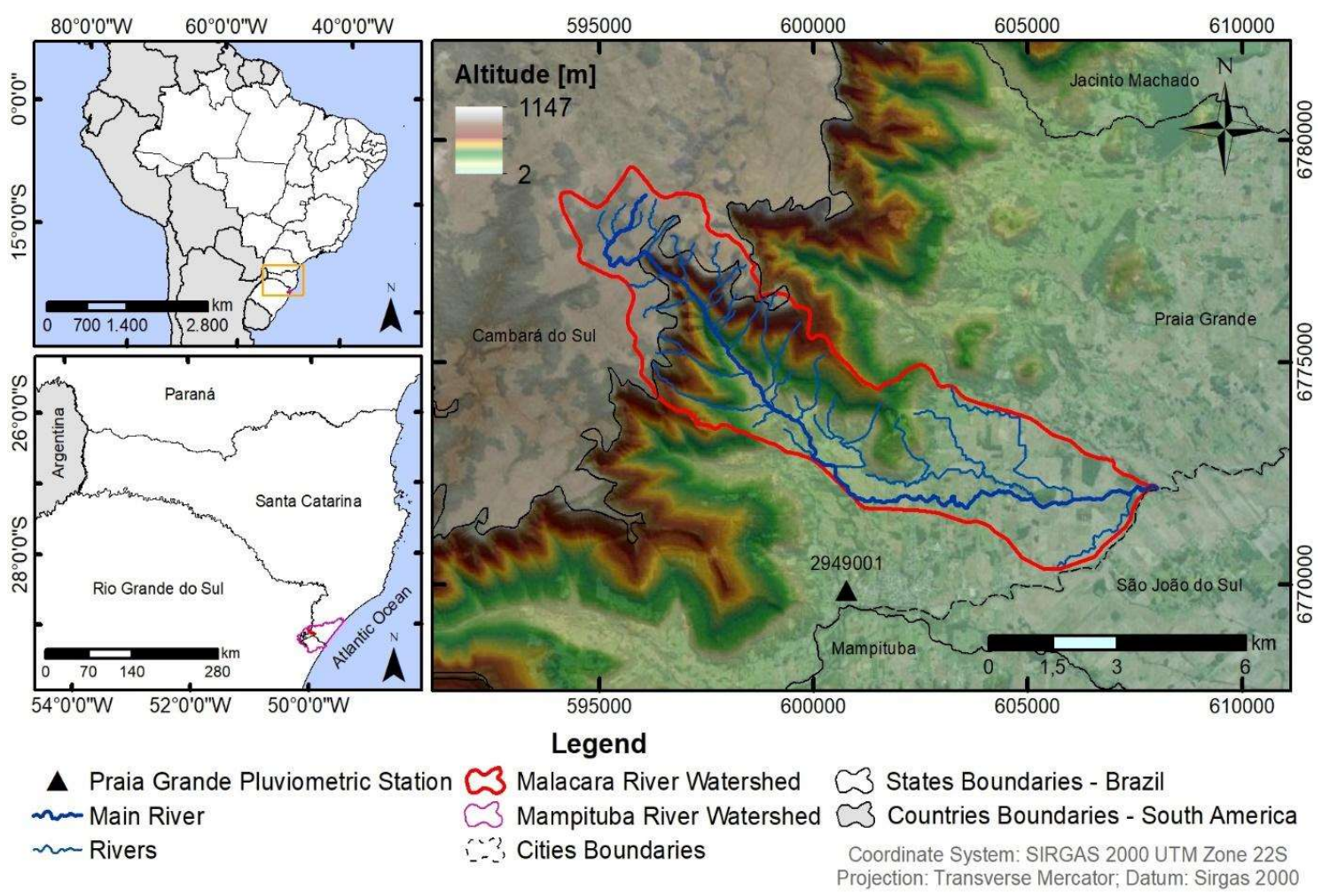

The rivers of the Malacara basin area are born in the cliffs of the Serra Geral formation (altitude of 1,100 m) and find, in a short distance $(10 \mathrm{~km})$, the floodplain (average altitude of $100 \mathrm{~m}$ ) where the Praia Grande City in Santa Catarina State is located (SZYMANSKI et al., 2019). The maximum altitude is $1,113 \mathrm{~m}$ at the top of the basin, on the cliffs of Serra Geral formation, and the minimum altitude is $17 \mathrm{~m}$ at the river mouth (Mampituba River). The region climate, according to the Köppen classification, is of the Cfa type, subtropical (humid mesothermal and with hot summers), with an average annual precipitation of 1,500 $\mathrm{mm}$ and an average annual evapotranspiration of 900 mm (PANDOLFO et al., 2002).

\section{2 Input spatialized data in the USLE model}

Orthorectified aerial photographs, soil map, and a Digital Terrain Model (DTM) were used as input data in the USLE model. Both aerial photographs (spatial resolution of $0.39 \mathrm{~m}$ ) and DTM (resolution of $1.0 \mathrm{~m}$ ) were obtained from the Santa Catarina Secretariat for Sustainable Economic Development - SDS (2013). However, the SDS DTM covers $97 \%$ of the total area of the river basin in Santa Catarina State. 
Thus, to complete the $3 \%$ coverage of the Malacara river basin, the DTM from the ALT Palsar satellite (Advanced Land Observing Satellite) of the National Aeronautics and Space Administration - NASA (2011) was used, which has a spatial resolution of $12.5 \mathrm{~m}$. In order to integrate the two DTMs, it was necessary to resample the MDT-ALOS pixels from $12.5 \mathrm{~m}$ to $1.0 \mathrm{~m}$ resolution. The soil map (scale 1:250,000) was obtained from the Brazilian Agricultural Research Corporation (EMBRAPA, 2004).

\section{3 USLE model input parameters}

Universal Soil Loss Equation (USLE)

To evaluate soil loss in the study area, the USLE model by Wischmeier and Smith (1978) was used. Back (2020) mentions that the USLE is an erosion model designed to predict the average soil loss over time, considering the runoff from specific areas, under precise management conditions and is defined by:

$$
A=\text { R.K.L.S.C.P }
$$

Where, $A$ is the average annual loss of soil per unit area $\left[\mathrm{t} \mathrm{ha}^{-1}\right.$ year $\left.{ }^{-1}\right] ; R$ is the rainfall erosivity factor [MJ mm ha-1 $\mathrm{h}^{-1}$ year-1 $] ; K$ is the soil erodibility factor $\left[\mathrm{th} \mathrm{MJ} \mathrm{mm}^{-1}\right] ; L$ is the length of the slope, and $S$ is the slope steepness $\left(\mathrm{m}^{-1} \mathrm{~m}^{-1}\right) ; C$ is the land use and management factor [dimensionless]; and $P$ is the conservation practices factor [dimensionless].

Rainfall erosivity factor $(R)$

The $\mathrm{R}$ factor is of great relevance in the quantification of energy produced by the impact of raindrops on the soil. Wischmeier (1959) defined erosivity as "the product of the kinetic energy of a given rainfall $(E C)$ by its maximum intensity in 30 minutes $\left.\left(I_{30}\right)\right)^{\prime \prime}$. According to Back (2020), for a more accurate determination of the $\mathrm{R}$ factor, continuous rainfall records measured in pluviographs must be analyzed. Cassol et al. (2007) mention that it is necessary to divide the rainfall diagram of each rain into uniform segments, calculate the kinetic energy of each segment, and multiply by the total energy of the largest amount of rain recorded in the period of 30 consecutive minutes. However, in places where rainfall data is not available, 
the $\mathrm{R}$ factor can be estimated by the accumulated rainfall data over 24 hours, using equations that relate erosivity to the rainfall coefficient $\left(R c_{i}\right)$, defined according to Equation (2).

$$
R c_{i}=\left(p_{i}\right)^{2} / P
$$

Where, $p_{i}$ is the monthly average precipitation of month $\mathrm{i}(\mathrm{mm})$; and $P$ is the average annual rainfall $(\mathrm{mm})$.

In this study, the Erosivity Index ( $E I_{30}$ ) was calculated by Equation (3) defined for the southern region of Santa Catarina State by Valvassori and Back (2014), with an $R^{2}$ of 0.9080, showing that the study had a satisfactory result. Therefore, it can be used.

$$
E I_{30}=45.1 \cdot R c-127.05
$$

The rainfall erosivity factor $(R)$ was calculated using the rainfall data from the Praia Grande rainfall station (code 2949001), located in the center of Praia Grande City (SC) at the coordinates: $29.1958{ }^{\circ} \mathrm{S}$ and $49.9633^{\circ} \mathrm{W}, 60$ meters above sea level. This station is the responsibility of the National Water Agency (ANA) and is operated by the Agricultural Research and Rural Extension Company of Santa Catarina State (EPAGRI/SC). The historical series used comprises a period of 43 years (1976-2019). The result of rain erosivity was attributed to the entire drainage area of the Malacara river basin.

Finally, to obtain the $R$ factor, the sum of the Erosivity Indices was performed, according to Equation (4).

$$
R=\sum E I_{30}
$$

\section{Soil Erodibility Factor (K)}

The $\mathrm{K}$ factor is a property of the soil that represents its susceptibility to erosion (WISCHMEIER; SMITH, 1978). Mannigel et al. (2008) report that, to determine the K factor, indirect methods are used due to the greater ease of obtaining the data, and in direct methods it is necessary to follow rules and structure experimental plots that require a long time to determine the final value. In this study, Equation (5), proposed by Wischmeier and Smith (1978), was used to calculate the K factor. 


$$
K=\left[\frac{0.1317 \times 2.1 M^{1.14}\left(10^{-4}\right)(12-a)+3.25(b-2)+2.5(c-3)}{100}\right]
$$

Where, $M$ is the parameter that represents the soil texture [dimensionless], $\alpha$ is the organic matter content [\%], $b$ is the soil texture class [dimensionless], and $c$ is the permeability of the soil profile [dimensionless].

$$
M=\left(\% \_s i l t e+\% \_t h i n s a n d\right) \times\left(100-\% \_c l a y\right)
$$

The $K$ factor was determined for the soils present in the study area, namely, Cambissoil, Gleysoil, and Neossoil (EMBRAPA, 2004). The parameters for calculating the $K$ factor (Equations 5 and 6) were obtained from the soil survey on the scale 1:250,000 of EMBRAPA (2004).

\section{Topographic Factor (LS)}

The LS takes into account the topography of the soil in the erosion process, which is represented by the length of the slope length $(L)$ and the slope steepness $(S)$ of the soil (BERTONI; LOMBARDI NETO, 2012). The LS factor represents the contribution of surface runoff to the water erosion process (MINELLA et al., 2010). Thus, the increase in the slope length $(\mathrm{L})$ intensifies total soil loss and in soil loss per unit area, due to the progressive accumulation of surface runoff in the downstream direction (lower slope). With the increase in the slope steepness $(\mathrm{S})$, the flow velocity and erosion resulting from surface runoff also rises (WISCHMEIER; SMITH, 1978).

The factors $L$ and $S$, when analyzed together $(L S)$, are extremely important in the quantification of sheet erosion in a given area, due to the carrying of soil particles related to the speed of runoff, which will indicate a greater or lesser sediment transport.

In this study, the maps containing the factors $L$ and $S$ were combined to form a single map that represents the topographic factor LS. To obtain the factors, a slope and accumulated areas of the Malacara river basin map were generated both from the DTM of SDS (2013). It is worth mentioning that the accumulated areas were obtained from the flow directions of the runoff flow determined in ArcGIS 10.3.1.

The flow direction defines the hydrological relationships between different points within a basin, indicating the predominant direction of the runoff. From the flow direction, 
the accumulated flow is obtained, adding the amount of pixel of the DTM in the runoff flow direction. The accumulated flow, also called the basin area, represents the drainage network of the river basin (SOBRINHO et al., 2010). To determine the topographic factor (LS), Equation (7) proposed by Moore and Burch (1986a, b) was used.

$$
L S=\left(\frac{A s}{22.13}\right)^{0,4}\left(\frac{\operatorname{sen}(\theta)}{0.0896}\right)^{1,3}
$$

Where As is the specific contribution area, which corresponds to the product of the accumulated flow and the pixel size $\left(1.0 \mathrm{~m}^{2}\right) ; \theta$ is the degree of slope.

Factor use and soil management and conservation practices

CP factors are directly related to land use and cover. When the objective is to estimate soil loss through erosion, these factors must be analyzed together.

Factor $C$ represents the relationship between the quantities of soil eroded under certain conditions of use and management and the losses arising from this same soil kept continuously uncovered, with cultivation operations (WISCHMEIER; SMITH, (1978).

Thus, for the definition of land use and cover information, a map was created using digital aerial photographs (SDS, 2013) with a spatial resolution of $0.39 \mathrm{~m}$ obtained in December 2010. This map was prepared in ArcGIS 10.3.1, using the Maximum Likelihood supervised classification method.

In this study, factor $C$ was defined based on the data shown in Table 1 proposed by Bertoni and Lombardi Netto (2012). For land use, the following classes were considered: (i) forest (native and exotic tree vegetation), (ii) fields for undergrowth vegetation (native and cultivated pasture), (ii) agriculture (rice, banana, corn, etc.), and (iv) exposed soil (area devoid of vegetation and dirt roads).

Table 1 - Land use and management factor (Factor C)

\begin{tabular}{cc}
\hline Land use and cover & C Factor \\
\hline Forests & 0.01 \\
Fields & 0.26 \\
Permanent agriculture & 0.29 \\
Exposed soil & 0.404 \\
\hline
\end{tabular}

Source: Bertoni and Lombardi Netto (2012) 
The factor $P$ is related to the conservation practices used in soil management. According to Cardoso et al. (2020), the $P$ factor is the relationship between the expected intensity of soil loss with the adoption of a particular soil conservation and management practice.

Thus, the $P$ factor was defined for the study area based on the data shown in Table 2, proposed by Bertoni and Lombardi Netto (2012).

Table 2 - Conservation practices factor (P factor)

\begin{tabular}{cc}
\hline Conservation practices & P factor \\
\hline Cords of permanent vegetation & 0.2 \\
Weeding and contour planting alteration & 0.4 \\
Contour planting & 0.5 \\
Planting down the hill & 1.0 \\
\hline
\end{tabular}

Source: Bertoni and Lombardi Netto (2012)

Soil loss $(A)$

The soil loss in the Malacara river basin was then determined by Equation 1 using the ArcGIS raster calculator and maps corresponding to factors $K, R, C P$, and $L S$.

\section{Results and Discussion}

\section{Rain Erosivity Factor (R)}

The results of rain erosivity are totally related to local precipitation and, the greater the precipitation, the greater the rain erosivity, increasing the probability of causing soil erosion. For the Malacara river basin, the estimated value of rain erosivity was 5,754.2 MJ $\mathrm{mm} \mathrm{ha} \mathrm{H}^{-1} \mathrm{~h}^{-1}$ year $^{-1}$. According to the classification proposed by Santos (2008) values between 5,000 and 7,000 MJ mm ha ${ }^{-1} \mathrm{~h}^{-1}$ year $^{-1}$ can be considered medium erosivity. This value corroborates with Back and Poleto (2018) who obtained erosivity values between 5,000 and $6,000 \mathrm{MJ} \mathrm{mm} \mathrm{ha-1} \mathrm{h}^{-1}$ year $^{-1}$ for the southern region of Santa Catarina State.

Other studies carried out in the southern region of Brazil, especially in Santa Catarina State and Rio Grande do Sul State, obtained similar results for rain erosivity. Back and 
Valvassori (2014), in a research carried out in Urussanga City in Santa Catarina State, found an annual mean value of 5,665 $\mathrm{MJ} \mathrm{mm} \mathrm{ha} \mathrm{m} \mathrm{h}^{-1}$. Back (2018), studying the region of the Planalto Serrano Santa Catarina State, obtained an annual average of 5546.8 MJ mm ha-1 $\mathrm{hm}^{-}$ ${ }^{1}$ for Lages City and 7579.3 MJ mm ha-1 $\mathrm{h}^{-1}$ for São Joaquim City. Eltz et al. (2013) determined for São Gabriel City in Rio Grande do Sul State the value of 6,432.4 MJ mm ha-1 $\mathrm{h}^{-1}$ year. All results can be classified as average annual rain erosivity, with the exception of São Joaquim City, which showed high erosivity.

\section{Soil Erodibility Factor $(K)$}

Table 3 shows the soil parameters (class, texture, \% of coarse sand, \% of fine sand, \% of silt, \% of clay, and organic carbon) determined for each class of soil in the Malacara river basin, which were obtained from the Bulletin Research and Development for Soils in the Santa Catarina State (EMBRAPA, 2004). The other factors were determined by the indirect method described by Wischmeier and Smith (1978), such as organic matter content (a), soil structure (b), and permeability (c). The parameters of texture content and erodibility were calculated by Equations (6) and (5), respectively.

Table 3 - Data used to calculate soil erodibility

\begin{tabular}{|c|c|c|c|c|c|c|c|c|c|c|}
\hline $\begin{array}{c}\text { Soil Class } \\
\text { SBCS 2nd } \\
\text { Level }\end{array}$ & Texture & $\begin{array}{l}\text { Coarse } \\
\text { sand }^{1} \\
\text { [mm] }\end{array}$ & $\begin{array}{l}\text { Fine } \\
\text { sand }^{2} \\
{[\mathrm{~mm}]}\end{array}$ & $\begin{array}{c}\text { Silt }^{3} \\
{[\mathrm{~mm}]}\end{array}$ & $\begin{array}{l}\text { Clay }^{4} \\
{[\mathrm{~mm}]}\end{array}$ & C & $\mathbf{a}$ & b & c & $\mathbf{M}$ \\
\hline Cambissoil & Clayish & 1 & 3.67 & 45.33 & 50 & 1.12 & 1.93 & 3 & 3 & 2450 \\
\hline Gleyssoil & Average & 44 & 12.67 & 20.34 & 23 & 1.25 & 2.14 & 3 & 3 & 2541 \\
\hline Neossoil & $\begin{array}{l}\text { Very } \\
\text { clayey }\end{array}$ & 2.67 & 2.33 & 35.33 & 59.67 & 2.23 & 3.84 & 3 & 4 & 1519.22 \\
\hline
\end{tabular}

Figure 2 shows the soils present in the study area and the $\mathrm{K}$ factor for each type of soil. Greater erodibility is observed in the Gleysoil, which correspond to only $2.6 \%$ of the area of the river basin. 
Figure 2 - Soil types map according to Embrapa (2004) and their respective soil

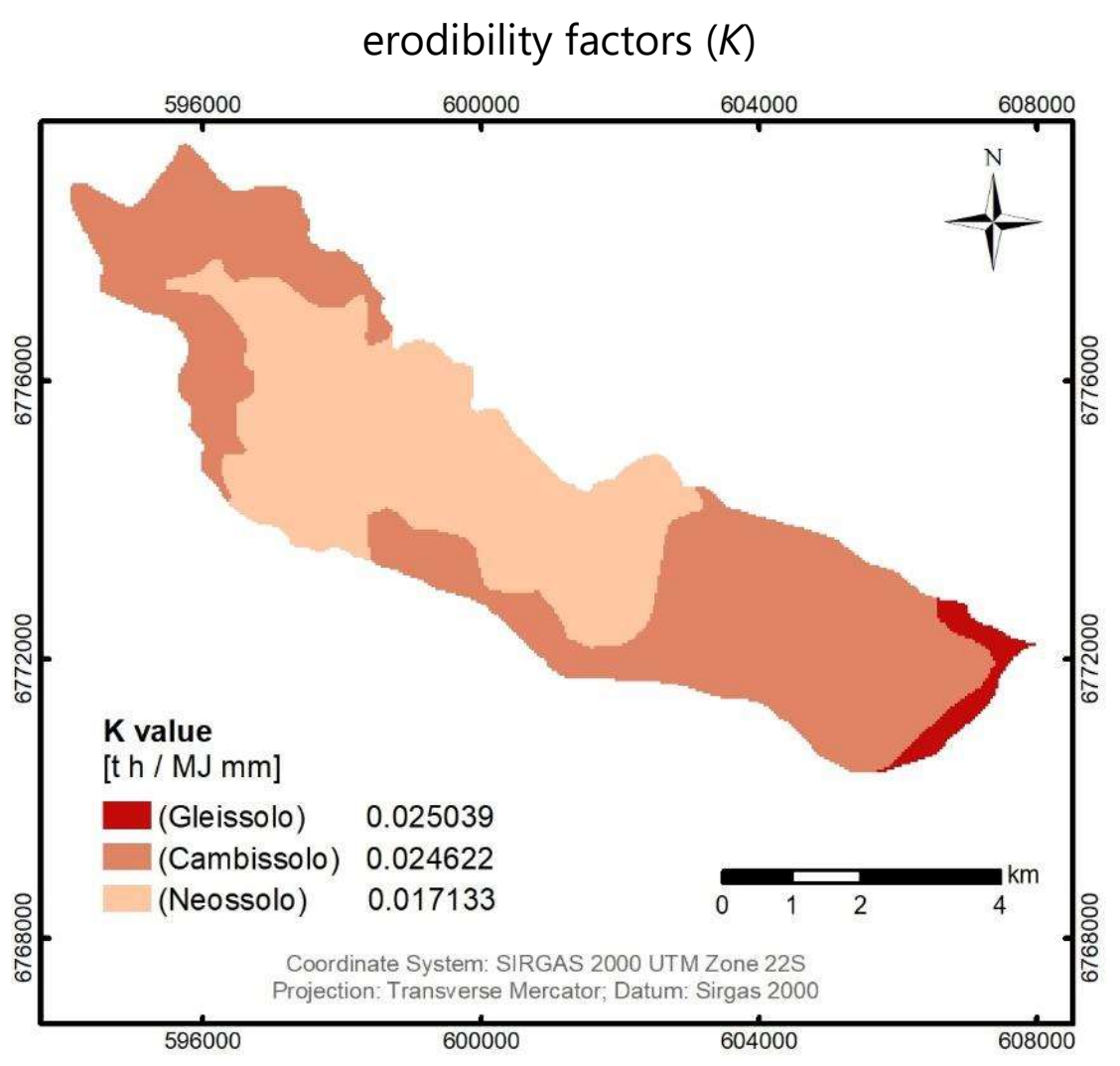

Cambisoils cover $54 \%$ of the total area $\left(22.04 \mathrm{~km}^{2}\right)$, and also have significant erodibility. Neossoils are the ones with less erodibility and represent $43 \%$ of the basin $(17.40$ $\mathrm{km}^{2}$ ). Neossoils are present, above all, in the areas with the highest declivity, as can be seen in Figures 2 and $3 a$ (declivity map).

It should be noted that the scale $(1: 250,000)$ adopted for the definition of soil types and the corresponding erodibility parameter $(K)$, may not accurately represent the variability of the river basin soils. However, in this study, soil profiles from the EMBRAPA survey (2004) were used since they are located as close as possible to the study area. The profiles used were: profile $\mathrm{n}^{\circ} 006$ with samples from Praia Grande City, profile $\mathrm{n}^{\circ} 018$ with samples from Jacinto Machado City and profile $n^{\circ} 040$ with samples from Araranguá City. These cities are located close to the study area (EMBRAPA, 2004).

However, for future research, it is suggested to carry out a more detailed soil survey to more accurately identify the characteristics of each soil. This, it is possible to improve the level of detail for soil classification and present other types of soil in the location. 


\section{Topographic Factor (LS)}

The study area has altimetric amplitude of $1,096 \mathrm{~m}$, varying from 1,113 m to $17 \mathrm{~m}$, with some areas with high slope. The configuration of the relief is characteristic of mountainous areas which can influence soil loss, correlating with the flow speed and carrying power of particles.

Regarding slope, areas with slope varying from 89.4 degrees were observed in the hillside areas, up to values close to 0 degrees in the floodplain predominantly located in the areas close to the river mouth, where agricultural areas are present, and also at the top of Serra Geral formation where there are floodplains of native countryside. The relief of the Malacara river basin was categorized according to the classification of the slope proposed by Embrapa (1979). Moreover, the Malacara river basin spatial distribution (Figure 3a) and the areas corresponding to each class (Table 4) were both determined.

Table 4 - Classification of the slope of the Malacara river basin according to EMBRAPA (1979) and their respective areas

\begin{tabular}{cccc}
\hline \multirow{2}{*}{ Slope [\%] } & Relief & \multicolumn{2}{c}{ Area } \\
\cline { 3 - 4 } & & {$\left[\mathbf{k m}^{\mathbf{2}}\right]$} & {$[\%]$} \\
\hline $0-3$ & Flat & 11.17 & 27.6 \\
$3-8$ & Gently wavy & 6.03 & 14.9 \\
$8-20$ & Wavy & 5.81 & 14.3 \\
$20-45$ & Heavily wavy & 7.32 & 18.1 \\
$45-75$ & Mountainous & 5.01 & 12.4 \\
$>75$ & Strongly mountainous & 5.14 & 12.7 \\
\hline
\end{tabular}

The relief varies from flat to heavily mountainous, with flat being the most predominant, covering $27.6 \%$ of the total area of the river basin. Areas with slopes between $20 \%$ and $45 \%$, classified as strongly undulating, is the second most representative class corresponding to $18.1 \%$ of the total area. The rest of the relief classes are close to the escarpments of the Serra Geral formation and are present in percentage areas below 15\% of the total. 
Figure 3 - a) Slope map of the river basin; b) Map of the topographic factor (LS)
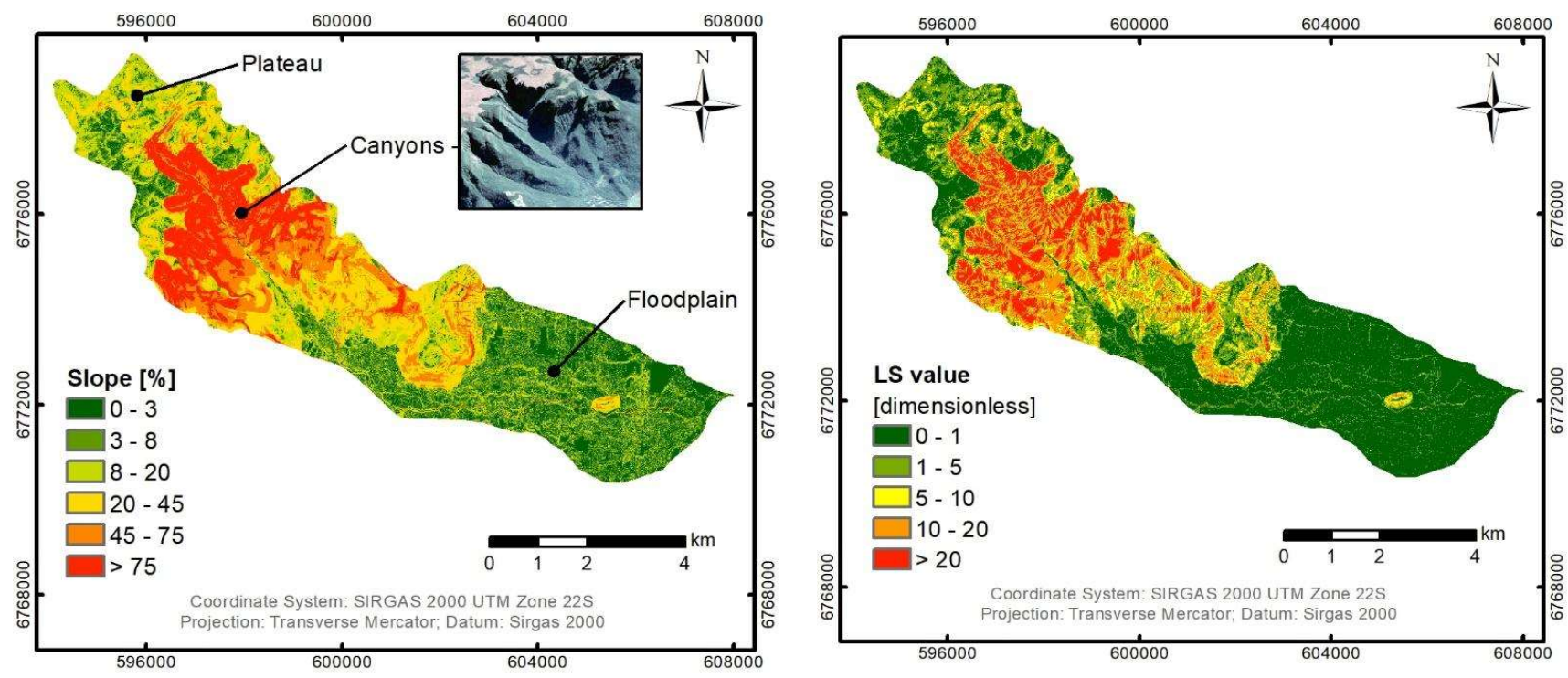

The LS factor represents the topographic potential for water erosion to occur. Figure $3 \mathrm{~b}$ shows that the values found ranged from 0 to numbers greater than 20 , indicating an area with low to very high surface runoff potential, respectively. In the river basin, areas with very low runoff rates predominate (52.3\% of the total area). The sites with high to very high runoff potential, $23.2 \%$ of the total area of the basin, are located close to the enclosed valleys, in the Malacara canyon where the slope is extremely high. In the plateau and in the floodplain, it is observed that the runoff rates are lower.

Table 5 - Classes of occurrence of the topographic factor defined by Bertoni and Lombardi Neto (2008) and their respective areas

\begin{tabular}{cccc}
\hline Surface runoff & Class & \multicolumn{2}{c}{ Área } \\
\cline { 3 - 4 } potential & [adimensional] & {$\left[\mathbf{k m}^{\mathbf{2}}\right]$} & [\%] \\
\hline Very low & $<1$ & 21.19 & 52.3 \\
Low & $1-5$ & 5.69 & 14.1 \\
Moderate & $5-10$ & 4.22 & 10.4 \\
High & $10-20$ & 5.29 & 13.1 \\
Very high & $>20$ & 4.09 & 10.1 \\
\hline
\end{tabular}


Land use and Management Factor and Conservation Practices (CP)

Figures $4 a$ and $4 b$ show the maps of land use and cover and the values corresponding to the CP factor, respectively. Table 6 shows the classes of land use and cover in the basin area.

Based on the values proposed by Bertoni and Lombardi Netto (2012) for the CP factor, the map in Figure 5a was reclassified, obtaining the values shown in Table 7. These values were defined based on the field knowledge of the study area.

Table 6 - Classes of land use and cover in the Malacara river basin and their respective areas

\begin{tabular}{ccc}
\hline Classes of land use and & \multicolumn{2}{c}{ Area } \\
\cline { 2 - 3 } cover & {$\left[\mathbf{k m}^{\mathbf{2}}\right]$} & {$[\%]$} \\
\hline Water & 1.53 & $3.8 \%$ \\
Agricultural crops & 9.37 & $23.1 \%$ \\
Pasture or native field & 5.17 & $12.8 \%$ \\
Exposed soil & 0.20 & $0.5 \%$ \\
Tree vegetation & 24.23 & $59.8 \%$ \\
\hline
\end{tabular}

According to the coverage and land use, the Malacara river basin is in good conditions of environmental preservation, having $59.8 \%$ of its area covered by tree vegetation, mostly composed of native forest. This occurs due to the steep slope found on the Serra Geral formation, constituting a strong restriction factor for the use of the soil for agricultural and livestock activities.

In the land use and cover map (Figure 5a), it is possible to observe that the agricultural area is quite expressive, and corresponds to $23.1 \%$ of the total area. In fact, irrigated rice is the main crop in the region which is found in the floodplain. Subsistence crops (maize, bananas, beans, cassava, etc.) are planted on the slopes of the Serra Geral formation.

(Continue...) 
Figure 4 - a) Land use and cover; map b) Land use and management factor and
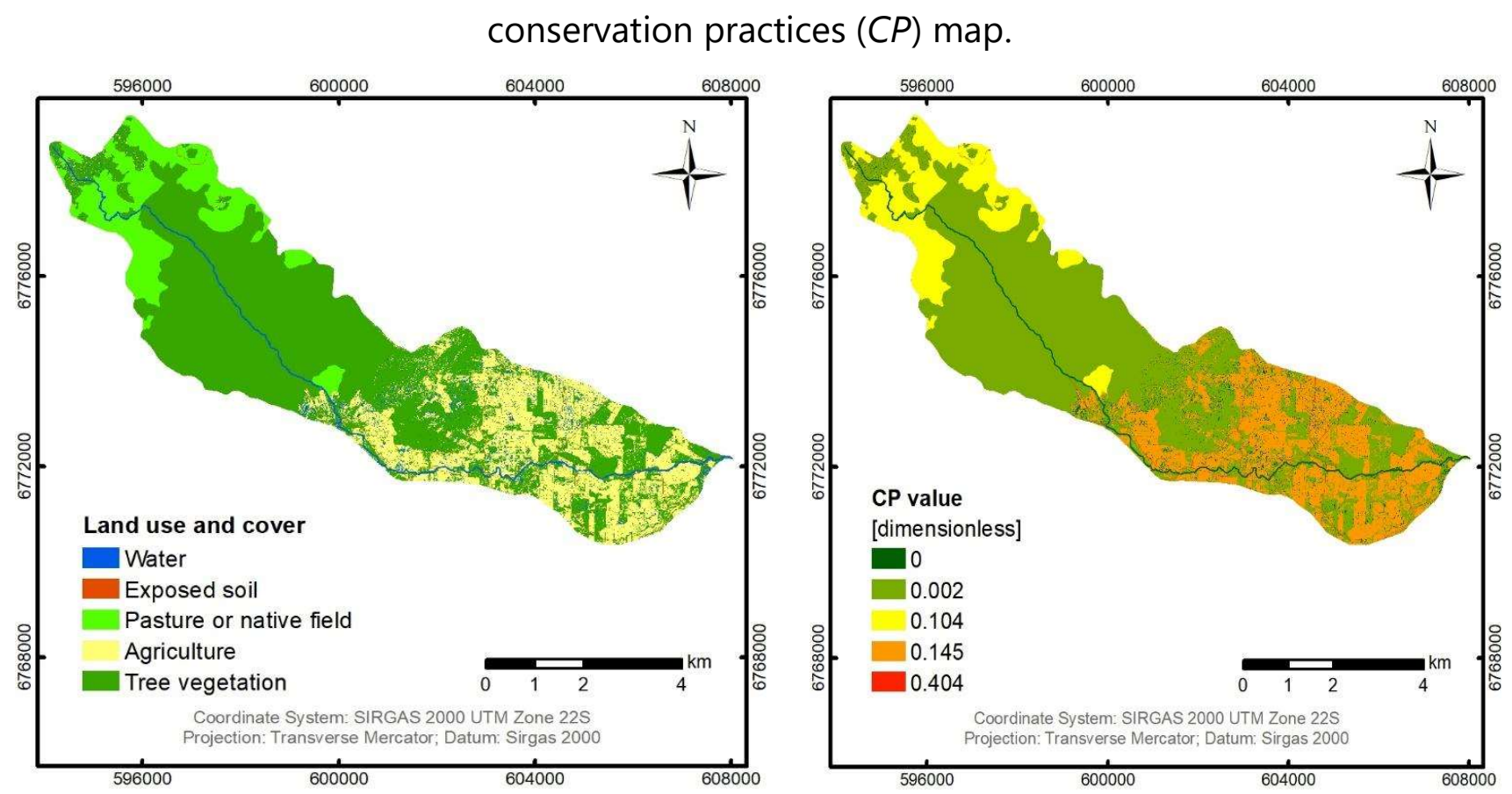

Table 7 - Land use and management factor $(C)$ and conservation practices factor $(P)$ applied to the study area

\begin{tabular}{cccc}
\hline Land use & C factor & $\boldsymbol{P}$ factor & CP factor \\
\hline Water & 0 & 0 & 0 \\
Tree vegetation & 0.010 & 0.2 & 0.002 \\
Pasture or native field & 0.260 & 0.4 & 0.104 \\
Agricultural crops & 0.290 & 0.5 & 0.145 \\
Exposed soil & 0.404 & 1.0 & 0.404 \\
\hline
\end{tabular}

In Table 7, the lowest $\mathrm{CP}$ values were obtained for tree vegetation cover, which represents areas with little or no agricultural soil management. This land use and cover provides greater protection of the soil against erosion during runoff processes (BARBOSA et al., 2015). The highest values, on the other hand, are associated with classes that provide little or no soil coverage (exposed soil and agricultural crops on the slopes of the mountains), making the soil highly vulnerable to water erosion.

Soil loss (A)

The values of soil loss in the Malacara River basin vary from 0 to more than $200 \mathrm{t} \mathrm{ha}^{-}$ ${ }^{1}$ year $^{-1}$. The soil loss classes, shown in Table 8, proposed by the Food and Agriculture 
Organization of the United Nations - FAO (1980) were used to interpret the degree of susceptibility to erosion.

Table 8 - Classification regarding susceptibility to soil erosion and their respective areas according to FAO (1980)

\begin{tabular}{|c|c|c|c|}
\hline \multirow{2}{*}{ Soil loss [t ha-1 year $\left.^{-1}\right]$} & \multirow{2}{*}{$\begin{array}{l}\text { Degree of sheet } \\
\text { erosion }\end{array}$} & \multicolumn{2}{|c|}{ Area } \\
\hline & & {$\left[\mathrm{km}^{2}\right]$} & [\%] \\
\hline$\leq 1$ & Normal & 19.70 & $48.7 \%$ \\
\hline $1-10$ & Slight & 15.68 & $38.7 \%$ \\
\hline $10-50$ & Moderate & 3.92 & $9.7 \%$ \\
\hline $50-200$ & High & 1.09 & $2.7 \%$ \\
\hline$>200$ & Veey high & 0.10 & $0.2 \%$ \\
\hline
\end{tabular}

Most of the river basin has a low degree of sheet erosion, ranging from normal to slight. The predominant type of erosion is normal $\left(A \leq 1.0 \mathrm{t} \mathrm{ha}^{-1}\right.$ year $\left.^{-1}\right)$ found in $48.7 \%$ of its total area. The second most expressive class is the degree of slight erosion (between 1 and $10 \mathrm{t} \mathrm{ha}^{-1}$ year $^{-1}$ ), occurring in $38.7 \%$ of the basin. The remaining $12.6 \%$ of the study area ranges from moderate to very high soil losses.

Figure 5 - Distribution of soil losses in the Malacara river basin

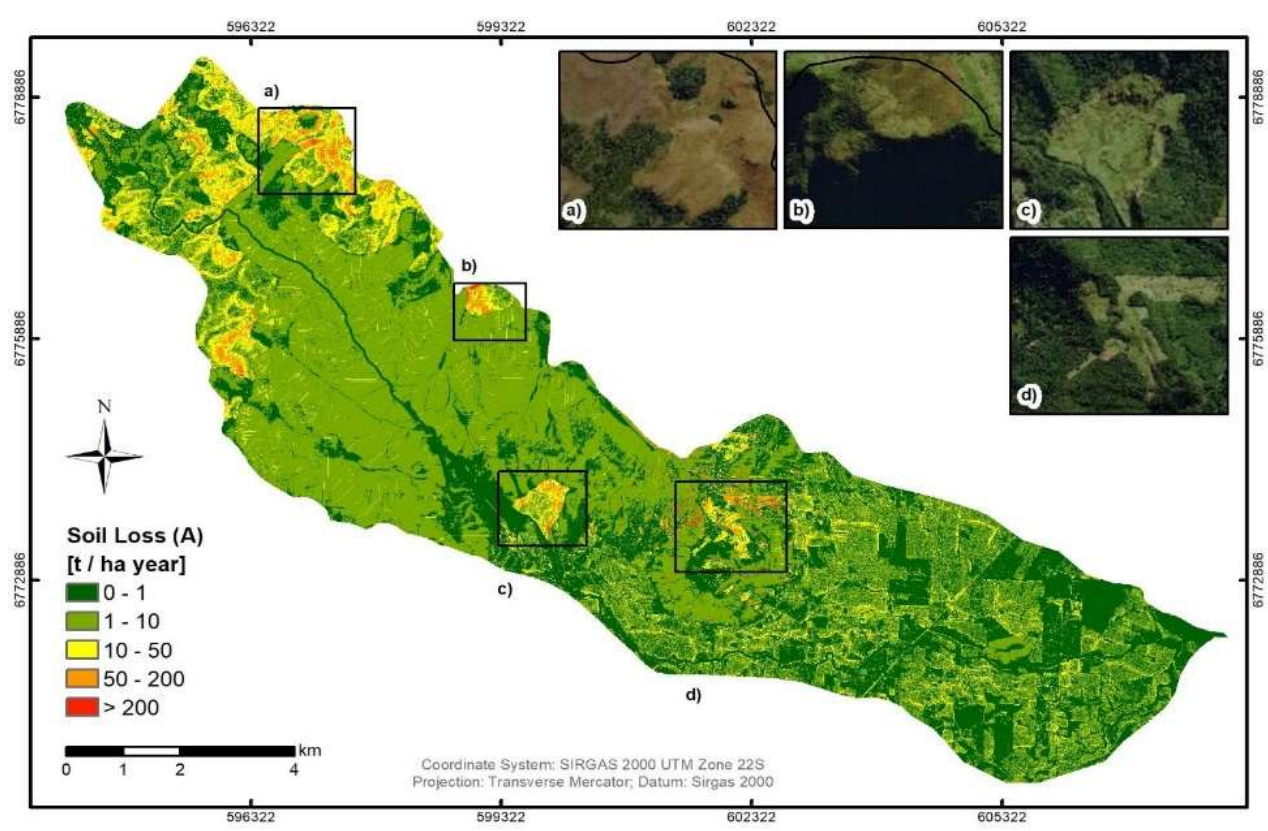


When analyzing the soil loss map, together with the maps of the factors used for its determination, it is observed that the spatialization of the erosion values is associated mainly with the topography (LS factor) and the use and cover of the soil (CP factor). The R factor was uniform for the entire river basin, while the $K$ factor showed a small variation in values between the soil classes present in the study area, thus presenting a low influence on the results of soil losses.

The determination of the soil loss map makes it possible to visualize the spatial distribution along the river basin, facilitating environmental planning and decision-making process regarding the suitability for anthropic activities of the river basin. In the soil loss distribution map, it is possible to identify critical points and direct efforts to the places most susceptible or affected by soil erosion, that is, to apply soil management and conservation practices (level cultivation, terraces construction, etc.), as well as defining an environmental preservation area (top of hills, slopes, and riparian zone).

\section{Conclusion}

The USLE model applied to the Malacara river basin allowed the identification of the areas most critical to sheet erosion, as well as those that need to be preserved to minimize the impact of water erosion on the soil. As this is a basin with a mountainous environment, it is crucial to know and understand the potential for water erosion of the soil, so that the activities developed in the region can be properly planned, aiming to preserve the environment surrounding water resources.

The loss of soil in the Malacara river basin ranged from 0 to more than $200 \mathrm{t} \mathrm{ha}^{-1}$ year1 , with $87.38 \%$ of the area showing a degree of sheet erosion normal to slight, $9.68 \%$ showing a degree moderate, and only $2.94 \%$ of the area has a high or very high degree of erosion. The results corroborate with the use and coverage of the soil in the Malacara basin, with $59.8 \%$ of the river basin having an area covered by tree vegetation, which provides greater protection to runoff and, consequently, less soil losses due to sheet erosion. 


\section{Acknowledgments}

The authors would like to thank the Coordination for the Improvement of Higher Education Personnel (CAPES) for the opportunity for research and financial support to make this study possible.

\section{References}

BACK, Á. J. Erosividade da chuva para a região do Planalto Serrano de Santa Catarina, Brasil. Revista de Ciências Agrárias. 2018;41(2):298-308.

BACK, Á. J. Informações climáticas e hidrológicas dos municípios catarinenses (com programa HidroClimaSC). Florianópolis: Epagri, 2020.157 p.

BACK, Á. J. Chuvas intensas e chuva para o dimensionamento de estruturas de drenagem para o estado de Santa Catarina. (Com programa HidroChuSC para cálculos). Florianópolis: Epagri, 2013. 139 p.

BACK, Á. J; POLETO, C. Distribuição espacial e temporal da erosividade das chuvas no estado de Santa Catarina, Brasil. Revista Brasileira de Climatologia. 2018; 22:381-403.

BARBOSA, A. F.; OLIVEIRA, E. F. MIOTO, C. L.; FILHO, A. C. P. Aplicação da Equação Universal de Perda do Solo (USLE) em softwares Livres e Gratuitos. Anuário do Instituto de Geociências: UFRJ. 2015;38:170-179.

BERTONI, J.; LOMBARDI NETO, F. Conservação do solo. 8th ed. São Paulo: Ícone; 2012. 335p.

BOHN, L. Expressões de conhecimento de grupos sociais locais para a gestão de recursos hídricos na bacia hidrográfica do rio Mampituba. UFSC: Reconhecimento da Bacia Hidrográfica do Rio Mampituba. 2008. 30 p.

CARDOSO, G.; ZANANDREA, F.; MICHEL, G. P.; POLETO, C. Aplicação da USLE na predição de perdas de solo em uma sub-bacia hidrográfica na região metropolitana de Porto Alegre RS. Congresso Internacional de Hidrossedimentologia. 2020. 3 p.

CARVALHO, N. O. Hidrossedimentologia Prática. 2nd ed. Interciência; 2008.

CASSOL, E. A.; MARTINS, D.; ELTZ, F. L. F.; LIMA, V. S. DE; BUENO, A. C. Erosividade e padrões hidrológicos das chuvas de ljuí (RS) no período de 1963 a 1993. Revista Brasileira de Agrometeorologia. 2007;15(3):220-231.

CUIABANO, M. N.; NEVES, S. M, A. S.; NUNES, M. C. M.; SERAFIM, M. E.; NEVES, R. J. Vulnerabilidade ambiental à erosão hídrica na sub-bacia do córrego do guanabara/Reserva do Cabaçal-MT Brasil. Geociências, UNESP. 2017;36(1):138-153.

ELTZ, F. L. F.; CASSOL, E. A.; PASCOTINI, P. B.; AMORIM, R. S. S. Potencial erosivo e 
características das chuvas de São Gabriel, RS, de 1963 a 1993. Revista Brasileira de Engenharia Agrícola e Ambiental. 2013;17(6):647-654.

EMBRAPA - Empresa Brasileira de Pesquisa Agropecuária. Serviço Nacional de Levantamento e Conservação de Solos (Rio de Janeiro, RJ). Súmula da 10. Reunião Técnica de Levantamento de Solos. Rio de Janeiro: 1979. 83 p. (Embrapa-SNLCS. Micelânea, 1).

EMBRAPA - Empresa Brasileira de Pesquisa Agropecuária. Solos do Estado de Santa Catarina. Rio de Janeiro: Embrapa solos; 2004. 721 p.

FAO - Food and Agriculture Organization. La erosión del suelo por el agua: Algunas medidas para combatirla en las tierras de cultivo. Cuadernos de fomento agropecuario de la Organización de Las Naciones Unidas, Roma: FAO; 1980; (81). 207 p.

FIORIO, P. R. Avaliação cronológica do uso da terra e seu impacto no ambiente da microbacia hidrológica do córrego do ceveiro da região de piracicaba - SP. Universidade de São Paulo; 1998. 130 p.

IVES, J. D.; MESSERLI, B. The Himalayan Dilemma: Reconciling Development and conservation. Routledge, London and New York, 1989. 324p.

KINNELL, P. L. A.; RISSE, L. M. USLE-M: Empirical modeling rainfall erosion through runoff and sediment concentration. Soil Science Society American Journal, v.62, 1998. p.1667-1672.

KINNELL, P. I. A. Event soil loss, runoff and the universal soil loss equation family of models: a review. Journal of Hydrology, v.385, 2010. p.384-397.

KOBIYAMA, M.; GOERL, R. F.; FAN, F. M.; CORSEUIL, C. W.; MICHEL, G. P.; DULAC, V. F. Abordagem integrada para gerenciamento de desastre em região montanhosa com ênfase no fluxo de detritos. Revista de Gestão e Sustentabilidade Ambiental. Florianópolis. 2018;7(esp):31-65.

KUKSINA, L. V.; GOLOSOV, V. N.; KUZNETSOVA, Y. S. Cloudburst Floods in Mountains: State of Knowledge, Occurrence, Factors of Formation. Geography and Natural Resources, vol. 38, 2017. p. 20-29, doi: https://doi.org/10.1134/S1875372817010036.

MELLO, C. R; VIOLA, M. R.; BESKOW, S.; NORTON, L. D. Multivariate models for annual rainfall erosivity in Brazil. Geoderma 202-203, 2013, 88-102.

MIQUELONI, D. P.; GIANELLO, E. M.; BUENO, C. R. P. Variabilidade espacial de atributos e perda de solo na definição de zonas de manejo. Pesq. Agropec. Trop. 2015;45(1):18-28.

MANNIGEL, A. R.; CARVALHO, M. P.; MORETI, D; MEDEIROS, L. R. Fator erodibilidade e tolerância de perda dos solos do Estado de São Paulo. Acta Scientiarum. Maringá. 2008. 24(5):1335-1340.

MINELLA, J. P. G.; MERTEN, G. H.; REICHERT, J. M.; SANTOS, D. R. Identificação e implicações 
para a conservação do solo das fontes de sedimentos em bacias hidrográficas. Revista Brasileira de Ciência do Solo. 2007;31:1637-1646.

MINELLA, J. P. G.; MERTEN, G. H.; RUHOFF, A. L. Utilização de métodos de representação espacial para cálculo do fator topográfico na equação universal de perda de solo revisada em bacias hidrográficas. Revista Brasileira de Ciência do Solo, 2010; 34:1455-1462.

MOORE. I. D.; BURCH, G. J. Modeling erosion and deposition: Topographic effects. Transactions of American Society of Agriculture Engineering. 1986a;29(6):1624-1630.

MOORE. I. D.; BURCH, G. J. Physical basis of the length slope factor in the Universal Soil Loss Equation. Soil Science Society of America. 1986b;50(5):1294-1298.

PANAGOS, P.; BALLBIO, C.; BORRELLI, P.; MEUSBURGUER, K.; KLIK, A.; ROUSSEVA, S.; TADIC, M. P.; MICHAELIDES, S.; HRABALÍKOVA, M.; OLSEN, P.; AALTO, P. O.; LAKATOS, M.; RYMSZEWICZ, A.; DUITRESCU, A.; BERGUERÍA, S.; ALEWELL, C. Rainfall Erosivity in Europe. Science of The Total Environment, v.511, 2015. p.801-814.

PANDOLFO, C.; BRAGA, H. J.; SILVA JÚNIOR, V. P.; MASSIGNAN, A. M.; PEREIRA, E. S.; THOMÉ, V. M. R.; VALCI, F. V. Atlas Climático do Estado de Santa Catarina. Florianópolis: EPAGRI, 2002. $334 \mathrm{p}$.

PANACHUKI, E.; SOBRINHO, T. A.; VITORINO, A. C. T.; CARVALHO, D. F.; URCHEI, M. A. Parâmetros físicos do solo e erosão hídrica sob chuva simulada, em área de integração agrícola-pecuária. Revista Brasileira de Engenharia Agrícola e Ambiental. 2006;10(2):261-268.

PINTO, S. A. F.; GARCIA, G. J. Experiências de aplicação de geotecnologias e modelos na análise de bacias hidrográficas. Revista do Departamento de Geografia. 2011;17:30-37.

REGINATTO, G. M. P; MACIEL, C. B.; CORSEUIL, C. W.; GRANDO, A.; MACCARINI, M.; HIGASHI, R. A. R.; FEILSTRECKER, L. B.; JÚNIOR, R. S. Avaliação das perdas de solo utilizando o modelo Rusle integrado a um SIG. XIX Simpósio Brasileiro de Recursos Hídricos. 2015.

RENARD, K. G.; FOSTER, G. R., WEESIES, G. A., MCCOLL, D. K.; YODER, D. C. Predicting soil erosion by water. A guide to conservation planning with the revised Universal Soil Loss Equation. USDA, Agricultural Handbook n 703. US Government Printing Office, Washington D. C., EUA. 1997.

SANTOS, C. N. El Niño, La Niña e a erosividade das chuvas no Estado do Rio Grande do Sul. Pelotas: Universidade Federal de Pelotas. 2008. 140 p.

SCHEIBE, F. et al. Atlas ambiental da Bacia do rio Araranguá: Santa Catarina - Brasil Florianópolis: UFSC: Cidade Futura, 2010. 64 p.

SANTA CATARINA. SDS. Levantamento aerofotográfico entregue aos municípios do Sul de Santa Catarina. Florianópolis: Secretaria de Desenvolvimento Sustentável, 2013. 
SOBRINHO, T. A.; OLIVEIRA, P. T. S.; RODRIGUES, D. B. B.; AYRES, F. M. Delimitação automática de bacias hidrográficas utilizando dados SRTM. Jaboticabal: Eng. Agríc. 2010;30(1).

STOFFEL, M.; WYŻGA, B.; MARSTON, R. A. Floods in mountain environments: A synthesis. Geomorphology. 2016;272:1-9.

SZYMANSKI, F. D.; KOBIYAMA, M.; BELLETINI, A. L.; VASCONCELLOS, S. M.; MAMÉDIO, F. M. P.; PAIXÃO, M. A.; CORSEUIL, C. W. Velocidade média dos rios montanhosos da região sul de Santa Catarina, Brasil. Porto Alegre: Anais do $5^{\circ}$ Simpósio sobre Sistemas Sustentáveis, 2019.

VALVASSORI, M. L.; BACK, Á. J. Avaliação do potencial erosivo das chuvas em Urussanga, SC, no período de 1980 a 2012. Viçosa: Revista Brasileira de Ciência do Solo. 2014;38:1011-1019.

WISCHMEIER, W. H. A rainfall erosion index for a universal soil-loss equation. In: Soil Science Society of America Journal. 1959. p. $246-249$.

WISCHMEIER, W. H.; SMITH, D. D. Predicting rainfall erosion losses: a guide to conservation planning. U. S. Department of Agriculture. 1978;(537):1-58.

WILLIAMS, J. R.; BERNDT, H. D. Sediment yield prediction and utilization of rangelands. Documentation and user guide. US Department of Agriculture, ARS 63, Washington. 1977. 